\title{
Role of Mineral Elements to Induce the Resistance of Arabica Coffee Against Rust Disease at Lowland Area
}

\author{
Muhammad Ghufron Rosyady ${ }^{1}$, Ketut Anom Wijaya ${ }^{1}$, Distiana Wulanjari ${ }^{1}$ and, Ali Wafa $^{2 *}$ \\ ${ }^{1}$ Agricultural Study Program, Jl. Kalimantan No 37 Bumi Kampus Tegal Boto Jember 68121, Indonesia \\ ${ }^{2}$ Plant Protection Study Program, Jl. Kalimantan No 37 Bumi Kampus Tegal Boto Jember 68121, Indonesia
}

\begin{abstract}
Lowland arabica coffee can be affected by leaf rust and its decrease the coffee production up to $80 \%$. The resistance level of the plant can be determined by the content of cellulose, lignin, calcium pectate, and polyphenols in leaf tissue. Many publications reported that the mineral element could increase the content of the metabolites. This study aimed to determine the effect of Si, B, I, Ca, and $\mathrm{K}$ on the incidence of leaf rust attack. The experiment was carried out at $400 \mathrm{~m}$ a.s.l. in 2018. The experimental subjects were KT variety, which was six years old. The experiment used a randomized block design with seven treatments. The results showed that there were 1) decrease the number of leaves affected by rust between first and second observation, and 2) compared to controls, all treatments has decreased the incidence of attacks leaf rust disease. Conclusion: There is a tendency of differences in the incidence rate of attack of leaf rust disease in each treatment. Control plants showed the highest incidence rate of $1.25 \%$, while the lowest incidence was affected by Silica, iodine, and potassium, which were $0.63 \%$. The treatment of silica and iodine was able to reduce the highest number of colonies Leaf Rust.
\end{abstract}

\section{INTRODUCTION}

Coffee is the most important agricultural commodity. Two main cultivated coffee species are $C$. canephora (Robusta coffee) and $C$. arabica. The main of the limiting factor of Arabica coffee (Coffea arabica) production worldwide is Coffee leaf rust [1].

Coffee leaf rust caused by Hemileia vastatrix. Its biotrophic fungi and the most important fungal disease. Its affecting coffee production. Although the use of fungicides can control the disease efficiently, the economically most favorable alternative is the use of resistant cultivars because it reduces the cost of production and has no negative impact on the environment [2]. The disease is currently managed through the use of protectant and systemic fungicides, including copper, triazoles, and strobilurins [3].

However, the susceptibility of arabica coffee is an important issue due to coffee leaf rust disease. Some treatment has done to tackle that problem like varieties building [4], by microbial inducer [5] and ecosystem management [6]. The plant nutrition management can use as an alternative method of reducing coffee rust and other fungal pathogens [7].

This research aimed to know the effect of several mineral éléments like $\mathrm{Si}, \mathrm{B}, \mathrm{I}, \mathrm{Ca}$, and $\mathrm{K}$ to plant resistance to the rust disease.

\section{MATERIAL AND METHODS}

\subsection{Sample plant criteria}

The criteria of coffee plant samples are productive Arabica Coffee with "Kartika 1 (KT)" Variety, within a minimum of three years old. Plant in low land area, 400 $\mathrm{m}$ above sea level and has been attacked by the fungal pathogen of coffee leaf rust.

\subsection{Environmental sampling for preliminary research}

The soil sample at the bottom of the coffee plant was taken at first for analysis of total N, P, K content. Furthermore, the plant treated by several mineral elements: calcium $(\mathrm{Ca})$, silica $(\mathrm{Si})$, iodine $(\mathrm{I})$, potassium $(\mathrm{K})$, boron $(\mathrm{B})$, and a combination of all elements

\subsection{Mineral treatment}

The randomized block design with seven treatments used in this research. The treatments used in sequence are 1) control (sprayed with aqua dest), 2) Ca (3000 ppm), 3) Si (150 ppm), 4) I (300 ppm), 5) K (20,000 ppm ), 6) B (300 ppm), and 7) $\mathrm{Si}+\mathrm{B}+\mathrm{I}+\mathrm{Ca}+\mathrm{K}$ and 4 repetitions. Mineral application techniques used are the foliar application. It applied with mist sprayer to the backside of the coffee leaf. $0.5 \mathrm{ml}$ of surfactant Solution added during mineral applications. The foliar application of the mineral repeated by five times with seven days interval on each repetition.

\footnotetext{
Corresponding author: muhammad.ghufron.rosyady@gmail.com
} 


\subsection{Disease Incidence Observation}

The rust disease incidence observed by count the attacked branches of the coffee plant in each treatment and the disease severity conduct by measure the rust colony diameter and number of rust colonies in each leaf sample. The observation was conduct before mineral application and seven days after the last application. Leaf Sample taken by chose four leaves in each coffee branch.

\subsection{Lignin and Cellulose Content Test}

The test of lignin and cellulose content in the tested coffee leaf conducted by followed Chesson methods [8]. The leaf samples were rooted and deseeded and the entire stem then sectioned into $12 \mathrm{~cm}$ lengths using a guillotine. Small sample sheaves $(20 \mathrm{~g})$ were prepared in triplicate from the sectioned material, dried overnight at $70^{\circ} \mathrm{C}$, and reweighed. Sample were immersed in $0.25 \%$ (w/v) RP in O.lM acetate buffer $\mathrm{pH} 4.5$ containing $0.002 \%(\mathrm{w} / \mathrm{v}) \mathrm{NaN} 3$ as a bacteriostat and incubated at 400e overnight. After incubation, sheaves were dried at $700 \mathrm{e}$ and the fiber then manually extracted (scutched) from the retted straw. The total weight of dry fiber obtained was expressed as a percentage of the dry weight of the sample sheaf $(\% \mathrm{TF})$. The $\% \mathrm{TF}$ values quoted are a mean of the values obtained from the three replicates.

\section{RESULT AND DISCUSSION}

Pathogenicity of biotrophic fungi influenced by host plant severity level. It affects the inoculation process of the fungal pathogen. The inoculation process of biotrophic fungi has a very complex mechanism, it starts by host recognition until host colonization.

The ingress process on the colonization process has a significant process for biotrophic fungi. Without succeeding in that process, the fungal pathogen became dying and failed to grow. The successfully of the ingress process can be affected by host plant physiological and biochemical. Related with the ingress process and according to the result, has been observed the treatment of mineral element can predispose the disease incidence of coffee leaf rust (Figure 1)

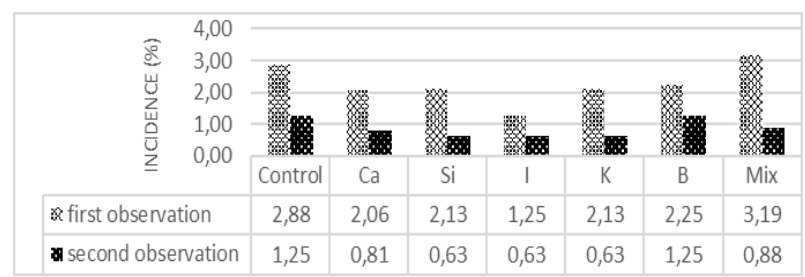

Figure 1. Leaf Rust Incidence on each Treatment

The difference in leaf rust incidence indicating how much the $H$. vastratrix can colonizing the leaf of the host plant on each treatment. Each treatment did not affect the colony growth of $H$. vastratrix directly, yet affects the biochemical of host leaf.
As biotrophic fungi, haustorium could be a significant part to support their life. It formation process influenced by the part of plant cell. The haustorium will be difficult to form on the high lignin content. Based on the result, the leaf rust incidence became lower on the higher lignin content. The significant process resulted on the iodium treatment. On that treatment indicate lowest disease incidence nor with highest lignin content (figure 2). That related with Schurt et al [13] The lignification process has the important rôle of defense mechanisme of coffee plant during the $H$. vastratrix infection. It become first barrier to tackle the inoculation hypae to penetrate the cell host.

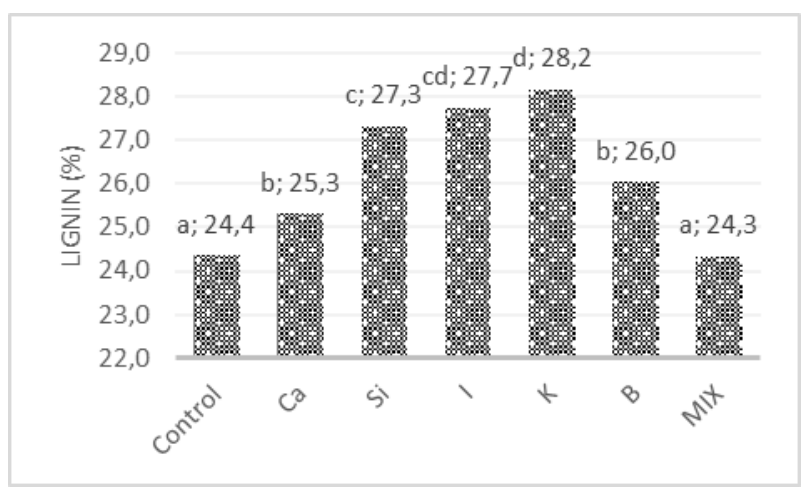

Figure 2. The lignin content on each treatment

Besides the lignin, cellulose also has a role for the resistance of coffee plants due to coffee leaf rust disease. Different from the lignin content result, the lowest incidence of coffee rust did not found in the highest cellulose content (figure 3). Based on the Hamid and wong [10], the primary effector of plant defense located on the activity of the plant bioactive signal during the pathogenicity process. However, the cellulose on the plant cell can be affected by several minerals to change their integrity and elasticity.

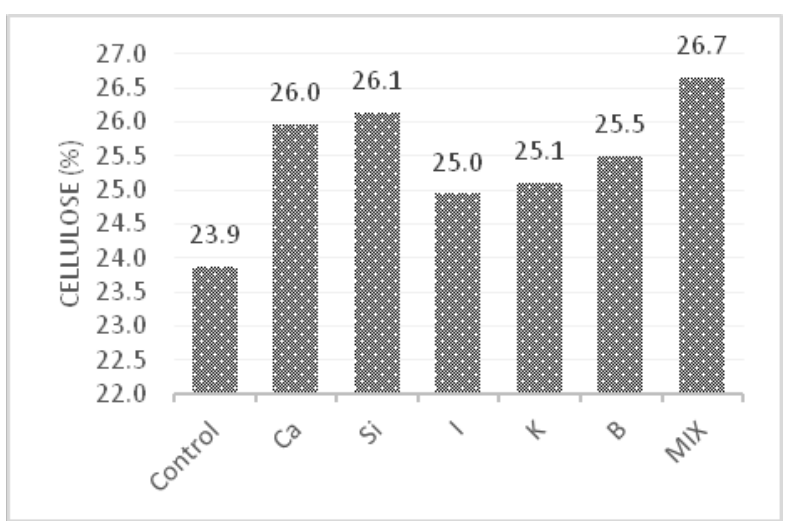

Figure 3. The cellulose content on each treatment

Based on Wang et al [11] the element enhanced to the plant resistance. It can increase the activity of defense-related enzymes, such as polyphenol oxidase, glucanase, peroxidase, and phenylalanine ammonialyase. That increasing the activity became as resulting on silicon enhancing. While undescribed well on the other component. However, the enhancing mineral element 
like Iodium, Silicon and other to the arabica coffee plant can develop to the mechanical control treatment to tackle the leaf rust disease.

\section{CONCLUSION}

The mineral element enhances the arabica coffee plant resistance due to biotrophic fungal attack. The mineral elements like I, Si and $\mathrm{K}$ can reduce the leaf rust incidence on the arabica coffee. Each component could act as an alternative way to tackle leaf rust disease on arabica coffee.

\section{ACKNOWLEDGMENT}

The research was done by the support of the Islamic Development Bank Project- University of Jember in 2018.

\section{BIBLIOGRAPHY}

1. Pedro Talhinhas et al. 2017. Molecular Plant Pathol. 18 (8) :1039-1051

2. T. Maiya et al. 2016. New Phytologist. 213: 13151329

3. L. Zambolin. 2016. Trop Plant Pathol 41:1-8

4. J. Vandermeer. 2018. Eur J Plant Pathol (2018) 150:1001-1010

5. F. Hajian-Forooshani et al. 2016. J. Environ Entomol, 2016, 1-6

6. J. Avelino et al. 2018. Ann. Rev. Phytopathol. Vol. 56:611-635

7. A Andrade Monteiro et al. 2016. J Phytopathol 164 1043-1053

8. Jin X et al. 2017. Bioresource Technology 241 (2017) 603-609

9. Schurt et al. 2016. Científica jaboticabal, 43(2), 318-325

10. Hamid S., Wong MY. (2017). In: Abdullah S., ChaiLing H., Wagstaff C. (eds) Crop Improvement. Springer, Cham

11. Wang et al . 2017. Interactions. Front. Plant Sci. 8:701. 1-14. 